Shushanik Isahakyan, Ph.D. student, Department of Economics and International Economic Relations, Yerevan State University,

Yerevan, Armenia

Olena Shkarupa

Ph.D., Associate Professor, Department of Economics, Entrepreneurship and Business Administration, Sumy State University,

Sumy, Ukraine

\title{
INNOVATION MARKETING TO ENHANCE COMPETITIVENESS: CASE OF ARMENIA AND UKRAINE
}

The growth of the country's competitiveness directly depends on the innovation of the business environment. The significant indicator of it can be considered through the ability of entrepreneurs to use innovative technologies to promote products and services, primarily to foreign markets. Therefore, the article takes forward a hypothesis about the existence of a positive influence of innovative marketing on the country's competitiveness. Using of innovative technologies for marketing research of the world market, the identification of new potential markets for exports, the diversification of the product line and services in foreign markets, the promotion of innovative developments of national producers to global markets other forms of displaying of innovative marketing - all this creates additional opportunities for more effective resource use of the country's competitiveness resource potential. Economic transformations both in Armenia and in Ukraine during the periods of post-crisis stabilization confirmed the effectiveness of innovative marketing technologies that were used in carrying out political, financial and infrastructural reforms. The article analyzes the current level of Armenia's competitiveness. It was found that a low level of ability to innovations is one of the main problems of Armenia's business environment; therefore the level of innovation in marketing is also low. The ways of implementation of innovative marketing tools are defined. It can contribute both to the growth of the country's competitiveness as a whole and to the solution of several problems: diversification of price strategies in foreign markets, the forming and promotion of the country's brand, enhancing the country's competitiveness potential through social media; promotion of products of national companies in world markets, encouragement of cooperation and collaboration between international partnerships, search for new spheres and technologies for export, changing the design of existing products with high potential of competitiveness in the foreign market, the development of new products and etc. The article proves by using the statistical methods of analysis that Armenia needs to diversify its exports both by countries and by-products. The indicator Enabling Trade Index (ETI-index) was studied as a characteristic of the country's foreign trade environment. The Holt method was used to get its prognostic data, which allowed to build exponentially-smoothed data series and to determine the trend values and to generate forecasts using the MS Excel package. The statistical base for this research was the retrospective data of the World Economic Forum on trade turnover for 2012-2016. The results showed that the ETI-index for Ukraine is lower than for Armenia, the trend towards the growth of ETI-index for Armenia was also revealed, while "market access" tends to decrease. This confirms the advisability of applying innovative marketing technologies to increase access to the domestic market, assistance for movement of goods, removing barriers to economic development and international integration.

Keywords: innovation, marketing, competitiveness of the country, innovation development, economic growth, price, design, Armenia, Ukraine.

Problem statement. Country competitiveness has a central role in both developing and developed countries. Competitiveness is crucial and by far the most critical factor for economic growth and future prosperity. Currently achieving profound external competitiveness is one of the main challenges of Armenia Government and Armenian exporters. Armenia as is Ukraine is a small, developing country that 
has limited resources and a rather small domestic market. Therefore, it needs to focus on the international markets and try to develop, produce commodities and services by using its resources most effectively. Currently, the primary export commodities are natural resources that cannot serve as a basis for long-term competitiveness thus Both Armenia and Ukraine need to use innovations both in production and marketing to achieve sustainable competitiveness. In a global market, currently, Armenia is facing a lot of challenges related to competitiveness, in particular, the insufficient ways of product promotion, low level of product awareness and visibility in international markets, lack of market access, etc. These two countries need to find ways of increasing current competitiveness and creating new possibilities for continuous competitiveness which can be possible by innovation especially innovations in marketing. It should be noted that in this article we will only concentrate on competitiveness issues and challenges that can be solved with the introduction of new ways of marketing that has never been used before. The abovementioned issues and challenges make the topic of article research relevant.

Analysis of recent researches and publications. Many scientists have devoted their researches to solve the general problems of the country competitiveness, among them are the following: Porter (Porter, 1990), Scott, B. R.; Lodge, G. C (Scott, 1985), Ali Asghar Negahdary (Ali, 2013) and others. Until recently, the subject of innovation marketing was not often raised in theoretical considerations. Innovation marketing concept is described in OECD manual (The Oslo, 2005) and the works of such scientists, as Dejanllić, Slavica Ostojić, Nemanja Damnjanović (Dejanllić, 2014), Meera Singh (Meera, 2012), Trott (Trott, 2004) and others. On the national level, every year National competitiveness report and Armenian Economic reports are being published however only a few volumes addresses the ways and mechanisms on how to enhance the export competitiveness. As for Ukraine, there is a primary problem of economic policy development, which will ensure the growth of the influence of innovation on economic growth. In Ukraine, the problems of innovative marketing in general and in some spheres (in industry, in the sphere of communications and the service sector) were studied by $S$. Voinarenko, N. Ilyashenko, M. Zyalik (Zayilik, 2011) and others. However, the researchers do not fully take into account the specifics of the promotion of goods and services to international markets in conditions of modern European practices.

Objective. The article aims to show that Armenia and Ukraine can solve some competitiveness challenge via using new ways of marketing. The goals this article are to analyze the concept of the innovation marketing and competitiveness, to identify factors which hinder competitiveness in global markets and give suggestions how to use effective marketing strategy and tools in particular, innovation marketing tools to build competitive products and successfully compete in global markets.

Main material. The nature of competitiveness. Nowadays competition is one of the main ways of interaction between human, firms, and nations. Countries compete for attaining more advantages, more power, more market share or profits, higher levels of development. In the $21^{\text {st }}$ century, with high levels of factor mobility, technological development, innovation and faster communication, competition becomes more and more intense and complex. And thus, the notion and nature of "competitiveness" becomes highly important and is widely used and interpreted. In economic literature, there are different definitions of country competitiveness. According to one competitiveness is determined by the productivity with which a nation, region, or cluster uses its human, capital, and natural resources. Productivity sets a nation's or region's standard of living (wages, returns on capital and returns on natural resources) (Porter, 1990). According to another definition, national competitiveness is a country's ability to create, produce, distribute, services and products in international trade while earning rising returns on its resources (Scott, 1985). We will give and use the following definition "Competitiveness is a country's capacity to develop, produce and sell competitive products in international markets.

The nature of innovation marketing. To sell products, the producers need to raise awareness and visibility of their products in global markets which would be possible by using effective marketing 
strategies. Marketing policy factors play an inevitable role and help a country to get a strong competitive position in exporting markets. Marketing includes the range and characteristics of the company's products, the price, and the creation of new products in line with consumer demand, knowledge of external and internal markets, customer service, and contacts with foreign customers, and promotional operations (Ali, 2013) marketing policy elements

The other important thing for achieving strengthening and maintaining competitiveness is innovations in marketing strategies. Innovation marketing uses all ingenious management activities that contribute to the promotion of the market success of the products and services. If one considers that the actual task and mission of innovation is a market success, it becomes clear that innovation marketing plays a vital role in the innovation process. Marketing innovation is the introduction of a new marketing method, in particular, product design change or packaging, product placement, product promotion or pricing. The goal of marketing innovations is to address customer demand and needs better, accessing the new markets, or newly position products on the competitive market, to increase the firm's sales. The distinguishing feature of innovative marketing is the implementation of a marketing method and ways not previously used by the firm. It can be part of a new marketing strategy and concept that represents a significant departure from the 50 firm's existing marketing methods. The ingenious ways of marketing can either be developed by the firm or adopted from other firms. New marketing methods can be applied to both new and existing products (Dejanllić, 2014). Innovation marketing is based on the following main concepts:

- Significant product design improvements (changes in form and packaging),

- Implementation of new pricing strategies,

- Implementation of an entirely new retail concept (introduction of completely new distribution channels), 2012).

- Implementation of an entirely new promotion concept (advertising on social networks) (Meera,

Marketing innovations include significant changes in the design of the products. Product design changes refer to changes in product form and appearance that do not change the product's functional or user characteristics. They also refer to alteration in the packaging of products such as foods, beverages, and detergents, where packaging is the primary component of the product's appearance. Product design changes can also include the introduction of significant changes in the form, appearance or taste of food or beverage products, for instance, the introduction of new flavours for a food product in order to satisfy the new targeted segment. An example of marketing innovation in packaging is the application of an entirely new design for a body lotion, with the purpose to give the product a new look and make them appealing for a new market segment (Dejanllić, 2014). The design is very crucial in a 21st century as it is all about getting attention, focusing it on the particular product and influencing the purchase decision of the customers. In the modern world, technology should be used to develop user-friendly new products with product differentiation. Packaging is used for raising the product's value. For an illustration, McDonald's had changed its package design across 118 countries. Packaging increases the perceptual experiences of the quality of the product (Trott, 2004). Marketing innovation of product packaging would include changes in the following elements: significant improvement of the packaging protective function, materials, reliability and satisfaction when opening and using packaging, considerable improvement of packaging identification that includes additional information on the use, promotional / sales actions, significant improvement of the package shape and size (Marketing).

Pricing innovations refer to the use of new pricing strategies and methods to market the firm's goods or services. An example of marketing innovation in pricing is the application of a new variable price/cost calculation based only on demand factors for a particular product or service. For example, change is the application of the method in the organization for the first time and involves the approval of discounts in the store for consumers that have specific credit or preferential cards issued by organizations. The pricing 
innovation includes the application of a new method and mechanisms for the calculation of the price and and cost of a good or service based on the demand (e.g. when the customers demand is low, the producers will decrease the price) or the introduction of a new mechanism which enables customers to choose desired product specifications (like computer memory) on the firm's Webpage and then see the price for the specified product (Dejanllić, 2014). For instance, Dell -computers producing tech giant allows its customers to choose the specification of the products and build their customized products.

New marketing methods and mechanisms in product placement mainly involve the introduction of new channels and ways of sale. Sales channels refer to the methods used to sell goods and services to customers and include the logistics methods (transport, storing and handling of products) which enable efficient distribution of the products thus mainly deals with efficiency. Examples of innovation marketing in product placement are the introduction of a franchising system, of direct selling or exclusive retailing, and product licensing. Innovations in product placement can include the use of new concepts for the product presentation. For instance the introduction of salesrooms for furniture which is redesigned according to the different themes, giving the customers a chance to view products in fully decorated rooms (Dejanllić, 2014). For instance L'oreal- a leading French cosmetics company with very successful products that are being sale everywhere all over the world. One way in which cosmetic companies usually market their products is by organizing exhibitions where people get to test makeup as well as other cosmetics like perfume for free. In order to reach more customers in this digital world, L'Oréal developed an App which is called the L'Oréal makeup genius. This app enables users to do a digital makeover (apply different makeups) and by doing so they were able to test the best makeups that suited their skin tones. The app was a huge success. It has been downloaded more than seven millions times (Innovation).

New marketing methods in product promotion involve the use of new concepts for promoting a firm's goods and services. For example, the first use of significantly different media or technique - such as product placement in movies or television programs, or the use of celebrity endorsements - is a marketing innovation. New marketing methods and mechanisms in product promotion involve the application of new concepts for promoting a firm's goods and services. For example, the first use of significantly different media or technique - such as product placement in movies or television programs, or the use of celebrity endorsements - is marketing innovation. Another example is branding, such as the development and application of an entirely new brand symbol which is aimed to position the firm's product on a new market or give the product a new image. The introduction of a personalized information system, e.g. obtained from loyalty cards, to tailor the presentation of products to the specific needs of individual customers can also be considered a marketing innovation (Dejanllić, 2014). For example, as a direct result of their feedback, Virgin America introduced an in-flight social network enabling passengers to connect during the duration of a flight. The airline recently produced an incredible six-hour video detailing an entire in-flight experience on fictional Blah Airlines. The (incredibly) long-form content was supported by a website and accounts on social media channels including Twitter and Instagram (The global, 2017).

Competitiveness current situation in Armenia. Currently, achieving profound external competitiveness is one of the main challenges of the Armenian Government. According to 2017-2018 Global competitiveness report, Armenia is the 78th among 138 nations in 2016. It has improved its position by 3 points compared to the previous year (The global, 2017; The global, 2006). The Global Competitiveness Index separates countries into three main stages: factor-driven, efficiency-driven, an innovation-driven, each implying a growing degree of complexity in the activities of the economy. China, Albania, Bulgaria, Romania, Ukraine are also efficiency-driven countries (National, 2008). According to Global competitiveness report, Armenia is the efficiency-driven country (The global, 2017; The global, 2006). In this stage, companies need to modernize the production processes, invest in the training of the workforce to upgrade the skills to produce high-quality goods and services. To maintain the competitiveness over the long-run, the companies need: to rely on the high quality of the higher education 
system that produces the graduates to be hired by the private sector; a competitive environment urging enterprises to keep customers needs first; a flexible labor-market regulation; well-functioning and sophisticated financial markets to get access to funding to modernize production processes and upgrade the quality of products; the ability to adopt new technologies; and large foreign markets as an untapped potential to reach sophisticated consumers worldwide (Socio-Economic, 2015). Most of the abovementioned can be achieved by adopting new forms of marketing, in particular by significantly improving exporting products designs and by implementing entirely new promotion concept (advertising on social networks).

According to $\mathrm{GCl}$ report the most problematic factors for doing business are access to financing, tax rates, tax regulations, corruption, inefficient government bureaucracy, foreign currency regulations, inadequately educated workforce, inadequate supply of infrastructure, insufficient capacity to innovate Inflation, policy instability, poor work ethic in national labor force, restrictive labor regulations, government instability/coups, poor public health, crime and theft. As it is shown in the list above the insufficient capacity to innovate is among the main problematic areas for doing business in Armenia, thus innovations in marketing are also low. The Extent of the marketing factor is $94^{\text {th }}$ among 138 countries, which indicates that Armenia is not using effective marketing strategies to be competitive (The global, 2006).

The analysis of the Armenian export for 2008-2017 reveals that the export overall shows an increasing trend in recent years (Figure 1). The 2008-2009 decrease was conditioned by the global financial crisis, while the export in 2015 declines as a result of the recent economic crisis in Russia. Compared to 2016 Armenian export increased by 25,2\% and was 2.42 billion USD in 2017.

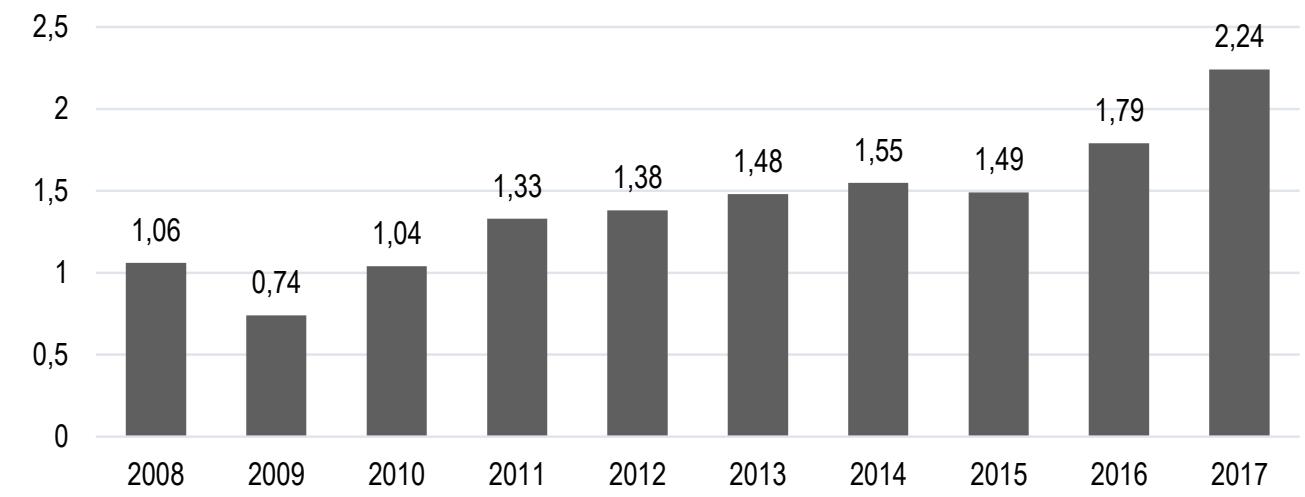

Figure 1 - Dynamics of Armenian export 2008-2017, billion USD (National Statistical Service,2016)

The figure 2 shows that the share of CIS countries in total exporting keeps decreasing in recent years and became $46 \%$ in 2017. In contrast, the percentage of other countries keeps growing and reached $26 \%$ in 2017. The share of EU countries has been fluctuating in recent years and was $28 \%$ in 2017 . The main trade partners are Russia, China, Bulgaria, Germany and Netherland.

The table below represents the top 10 export products of Armenia during 2017 at the 4-digit Harmonized Tariff System (HTS) code level.

Armenia's top 10 exports were $84.9 \%$ of total export, thus the Armenian export is not diversified as it is mainly exporting natural resources. Moreover, the Armenian products that are being exported to CIS countries are more diversified than products that are being exported to EU which is a result of packaging, labelling and other requirements by EU. However, Armenian export by EU countries is more or less diversified while by CIS it is not as the more than $93 \%$ of export is going to Russia. It is obvious that 
Armenia needs to diversify its export both by country and by product. Armenia can achieve product diversification by using innovation marketing, in particular developing new products, changing the design of existing products. To achieve a sustainable competitiveness in the global market it should conduct the research to reveal international customers' demand and develop its capacities to produce competitive products.

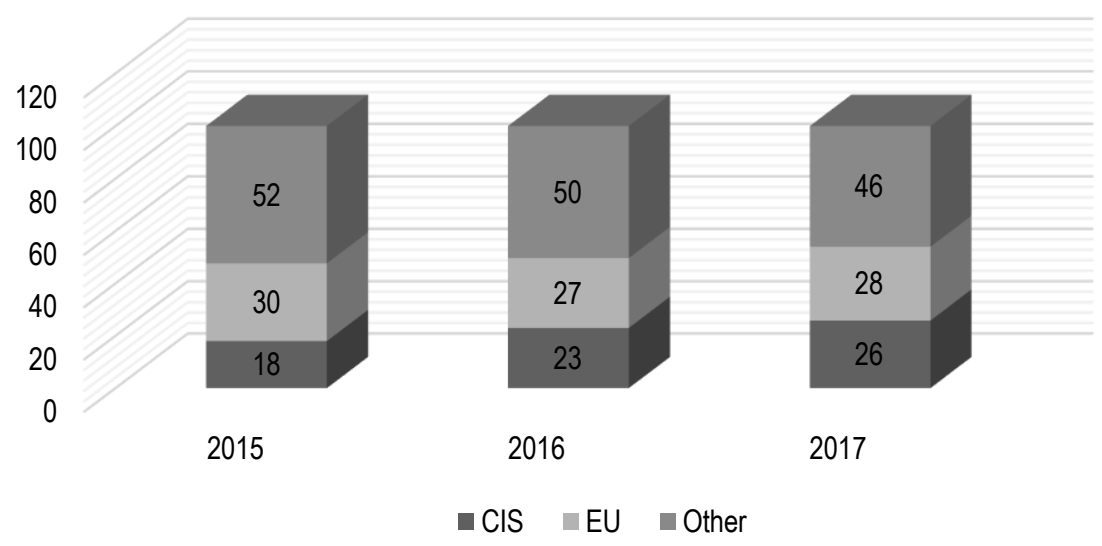

Figure 2 - Export structure by country group, 2015-2016 percentage (National Statistical Service, 2016)

Table 1 - Top 10 export products of Armenia during 2017 at the 4-digit Harmonized Tariff System (HTS) code level, million USD, percentage (Armenia's Top 10 Exports, 2018)

\begin{tabular}{|c|c|c|}
\hline 4- digit HTS & Million USD & Percentage \\
\hline Ores, slag, ash: & 615.1 & 30.1 \\
\hline Tobacco, manufactured substitutes: million & 242.4 & 11.9 \\
\hline Beverages, spirits, vinegar: million & 238.3 & 11.7 \\
\hline Gems, precious metals: million & 210.2 & 10.3 \\
\hline Aluminum & 106.2 & 5.2 \\
\hline Iron, steel & 87.2 & 4.3 \\
\hline Copper & 78.7 & 3.9 \\
\hline Mineral fuels including oil & 71.8 & 3.5 \\
\hline Clothing, accessories (not knit or crochet) & 43.1 & 2.1 \\
\hline Furniture, bedding, lighting, signs, prefab buildings & 39 & 1.9 \\
\hline
\end{tabular}

According to the exporter's research, the exporters find the product packaging a serious problem for Armenian Exporters. The low quality of packaging, the lack of graphics and structural design prevents exports from being competitive in the global market (Annual, 2012). As a result of technical standards and requirements, there are cases when the exported goods are denied, the quality of the goods is formulated in a lower category, fines are imposed on exporters and so on. According to global enabling reports Armenia is facing following exporting challenges, in particular, identification of potential markets and products, international technical standards and requirements that can be solved by above-mentioned innovation marketing strategies (Global, 2004).

Armenia expects more favourable and free entry into European markets for which it is mandatory to ensure adequate quality standards and infrastructure. The existence of production and quality infrastructure compliant with European market requirements will allow easily meeting entry conditions into 
a number of other developed markets. Introduction of the new design that is compatible with international standards will make Armenian products competitive in global markets and will enhance the levels of export. In order to minimize the challenges of technical standard and requirements, Armenia can make it possible in a contractual way, with a detailed market analysis and study of foreign laws and regulations. After that Armenia should invest in marketing innovations to create products with new design product. The adoption of the technical regulations and standards will define the specifications, dimensions, shape, design, function and productivity of the product or the labelling and packaging methods which will enable to produce competitive products. According to exporter's assessment, incomplete researches of foreign markets or absence of such (33\% of respondent companies) and problems in supplying to those markets $(30 \%)$ are the major obstacles or constraints to exports growth (Armenia, 2012).

Armenia can improve market access with following steps, which is in line with strategic development strategy of the RA Government:

- The revelation of potential export goods and partners (marketing);

- Introduction of the potential export goods via trade representatives;

- Support international fair participation;

- Organization of internal and external business visits and forum;

- Country and product branding at targeted countries;

- Supporting the development of sale associates in different countries (RA Strategic, 2014).

Competitiveness current situation in Ukraine. Following the results of 9 months of 2017, exports of goods and services amounted to $\$ 38.1$ billion and increased by $\$ 6$ billion compared to the same period in 2016. This was reported by the press service of the Ministry of Economic Development Exports of Ukrainian goods amounted to $\$ 31.3$ billion, services - $\$ 7.8$ billion, i.e. $82.3 \%$ accounted for exports of goods; $17.7 \%$ is the export of services. The growth in the volume of rendered services was $\$ 694.8$ million $(+9.8 \%)$, goods $-\$ 5.4$ billion $(+21.1 \%)$. In the structure of exports of goods, the largest share was made by-products of the agro-industrial complex and food industry $(41.3 \%)$, metallurgical products $(23 \%)$, machinery products $(11.4 \%)$ and mineral products $(9.5 \%)$. The export of sunflower oil (by $\$ 687.6$ million) in corn (by $\$ 641.4$ million) rape seeds (by $\$ 312.3$ million) of sugar (by $\$ 136.2$ million) increased during the period of 9 months of 2017. It is noted that the main trade partner of Ukraine in the export of goods remains the European Union - its cumulative share was $40.2 \%$. At the same time, the markets of the CIS countries are still traditional for Ukrainian producers: in January-September, 2017, the share of exports of Ukrainian goods to the CIS markets was $16.1 \%$, while Russia's share was $9.4 \%$. The volume of Ukrainian exports of goods to the EU countries in January-September 2017 relative to the same period of 2016 increased by $\$ 2.8$ billion $(29.1 \%)$ - in terms of value this is the largest growth in exports of goods of all partners of Ukraine. In the export of goods to the EU countries, there is a positive dynamics in all branches of industry. In the top 10 largest partner countries of Ukraine, except for the EU and Russia, is also Turkey - it accounts for $5.8 \%$ of the total exports of Ukrainian goods, India - 5.1\%, China - 4.5\%, Egypt - 4, 5\%, Belarus - 2.6\%, the USA - 1.9\%, Moldova - 1.6\%, Iran - 1.4\% (The Ukrainian, 2017).

In recent years imports in Ukraine have been chronically outperforming exports, and their difference sometimes up to $8 \%$ of GDP (Figure 3).

It should be noted that we do not aim to identify the advantages or disadvantages of each country development. We concentrate on identifying and deep analysis of the competitiveness challenges of them in order to develop more comprehensive innovation marketing and competitiveness strategy on the basis of identifying bottlenecks for the promotion of innovation at the national level. In this case, the Enabling Trade Index (ETI- index) can help to show the measures the factors, policies and services that facilitate the trade in goods across borders. Market access is one of the sub-indexes. It assesses different aspects of a country's trade environment. 


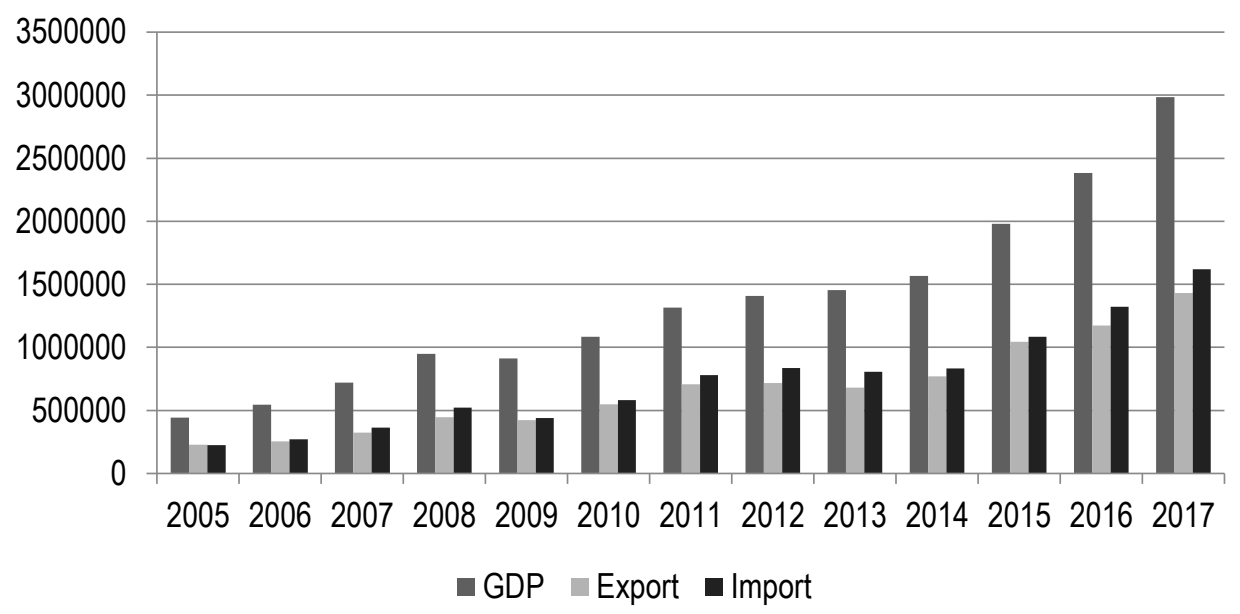

Figure 3 - The foreign trade balance of Ukraine from 2005 to 2017, million UAH (MinFin, 2017)

Results. To calculate the predictive values of the ETI-index, the Holt method is used. We propose to predict time series when there is a tendency to increase or fall in the values of the time series. It is also used for series when data is not a complete cycle, and seasonality cannot yet be identified (for example, for an incomplete year for the forecast by months).

Calculation of exponentially-smoothed series is carried out by the formula (Sineviciene, 2018):

$$
L_{t}=k \times Y_{t}+(1-k) \times\left(L_{t-1}-T_{t-1}\right)
$$

where $L_{t}$ is a smoothed value for the current period; $k$ - smoothing factor of the row; $Y_{t}$ - current values of the row of the indicator; $L_{t-1}$ - smoothed value for the previous period; $T_{t-1}$ - trend value for the previous period.

The values of the trend are found by the equation (Sineviciene, 2018):

$$
\left.T_{t}=b \times\left(L_{t}-L_{t-1}\right)+(1-b) \times T_{t-1}\right)
$$

where $T_{t}$ is the trend value for the current period; $b$ - smoothing factor of the trend; $L_{t} i$ is an exponentially smoothed value for the current period; $L_{t-1}-$ an exponentially smoothed value for the previous period; $T_{t-1}$ - trend value for the previous period. The trend value for the first period is $0\left(T_{1}=0\right)$.

This allowed to construct exponentially-smoothed rows of each of the indicators, to determine the values of trends and to generate forecasts using the MS Excel. The statistic base for this study is the retrospective data of the World Economic Forum's Enabling Trade Report for 2012-2016.

In order to develop models for the research and to form the prognosis hypothesis, we performed on the predicted values of the ETI-index for Ukraine and Armenia. Based on the scientific approach to time series forecasting (using the Holt method), the calculations were made. The results of forecasting the potential of the ETI-index for Ukraine and Armenia are given in Figure 4, 5 (The Global, 2017). 


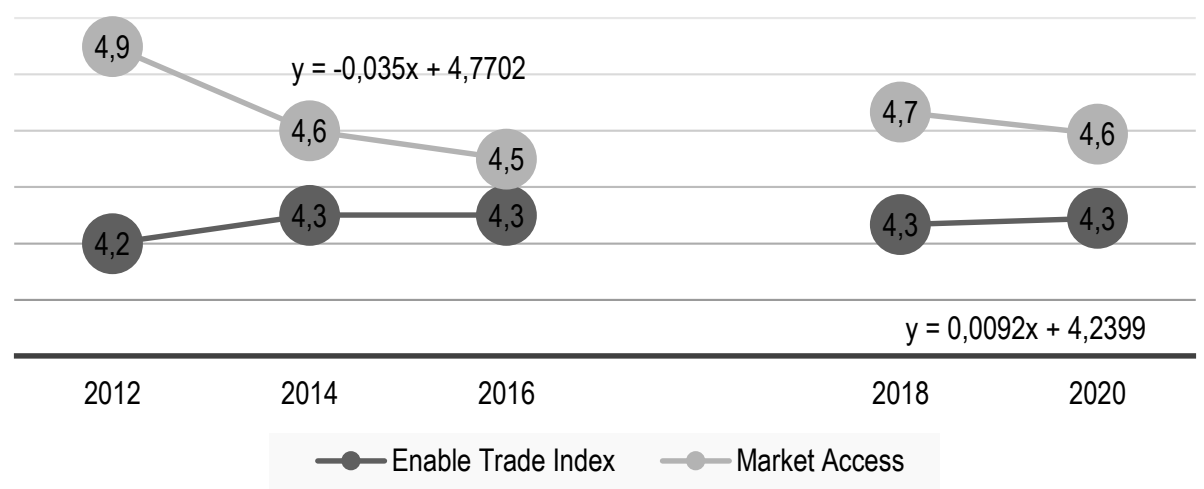

Figure 4 - Forecasting ETI-index of Armenia by the Holt method (formed by authors)

The Figure 4 shows that the ETI-index of Armenia is growing, while the "market access" tends to decrease. The forecast values that were obtained confirm this trend. Innovative marketing can help to increase the level of access to domestic markets, which in turn will positively affect the dynamics of the ETI-index.

In Ukraine, the overall level of the index is lower than in Armenia. The tendencies inherent in Armenia are true for Ukraine (Figure 5).

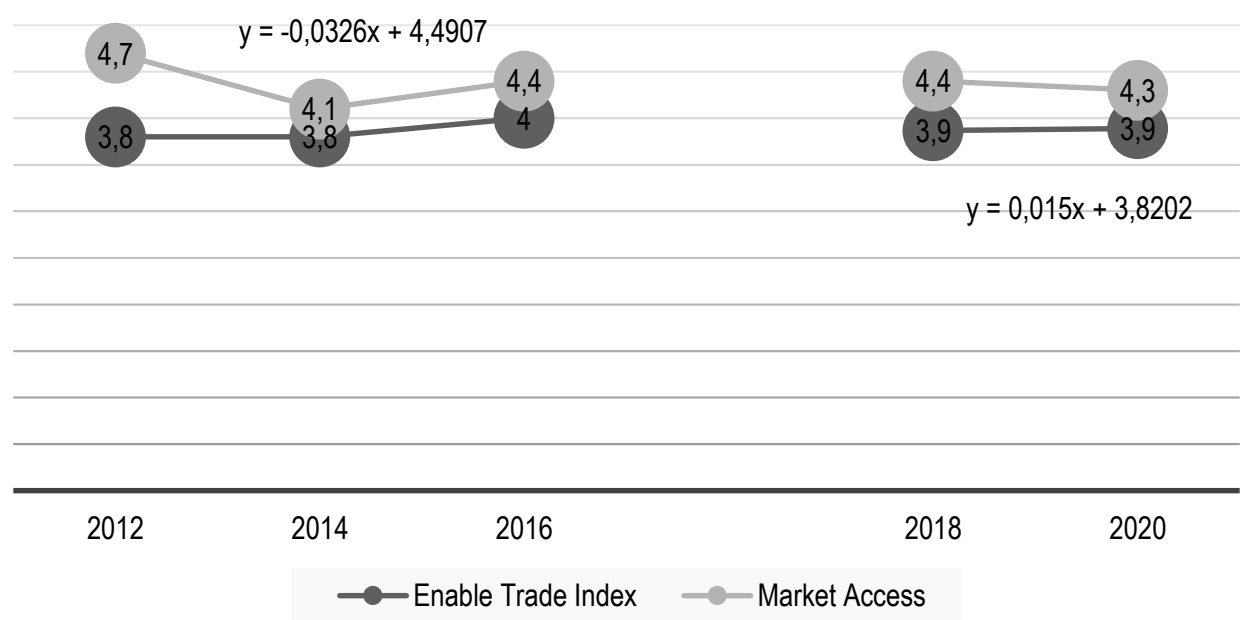

Figure 5 - Forecasting ETI-index of Ukraine by the Holt method (formed by authors)

The analysis ETI-index shows the effectiveness of countries in the field of international trade and the development of economic cooperation. The study shows how state institutions, policies and infrastructure contribute to the free movement of goods. The index forecast can be used by the government that should strive to eliminate obstacles to economic development and international integration. It can be used as a tool to analyze the problems in their economic policies and develop measures to improve the situation.

Taking into account the results of the research we recommend that Armenia and Ukraine should 
concentrate first on the development of current capacities that is the concentration on current exporting products and later try to create new capacities. Table below illustrates innovation marketing steps that can apply during each stage of competitiveness enhancement.

Table 2 - Innovation marketing steps for competitiveness enhancement (author proposition)

\begin{tabular}{|c|c|c|}
\hline \multirow{5}{*}{ 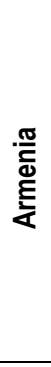 } & Development of current capacities & Creation of new capacities \\
\hline & $\begin{array}{l}\text { Adoption of the technical regulations and } \\
\text { standards }\end{array}$ & Analyze different countries markets and requirements \\
\hline & $\begin{array}{l}\text { Improvement of current exporting products } \\
\text { form and appearance }\end{array}$ & Create new products that will satisfy foreign demand \\
\hline & $\begin{array}{l}\text { Develop new packaging for currently exporting } \\
\text { products }\end{array}$ & Customization of products \\
\hline & $\begin{array}{l}\text { Introduction of discounts in the new markets for } \\
\text { consumers that have specific credit or } \\
\text { preferential cards issued by organizations }\end{array}$ & Introduction of specialized points of sales \\
\hline \multirow{6}{*}{ 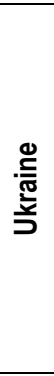 } & Development of current capacities & Creation of new capacities \\
\hline & $\begin{array}{l}\text { Modernization of the institutional and technical } \\
\text { regulations and standards }\end{array}$ & Analyze different countries markets and requirements \\
\hline & $\begin{array}{l}\text { Improvement of exporting products form and } \\
\text { appearance, the process of comparing a new } \\
\text { product }\end{array}$ & $\begin{array}{l}\text { Customization of products, create new products that } \\
\text { will satisfy foreign demand }\end{array}$ \\
\hline & $\begin{array}{l}\text { Provide strong government support to } \\
\text { Ukrainian enterprises }\end{array}$ & Ukraine's export potential for the European market \\
\hline & Consumer awareness & Introduction of specialized points of sales \\
\hline & Product planning, R\&D policy, Focus strategy & Celebrity endorsement, product placement and etc \\
\hline
\end{tabular}

In the context of how to increase the "market access" through innovative marketing, many activities related to market analysis, the development of a strategic focus of an enterprise for the development of a new product and the implementation of these strategies can be identified. To achieve success in the implementation of its products, it is necessary to use strategic methods associated with the development of new technologies.

Conclusions and recommendations for further research. This article examined the relationship between innovation in the marketing practices of firms and competitiveness that offer their products in the global markets. The analysis of the current competitiveness situation both of Armenia and Ukraine, in particular, market accessibility, lack of export commodities diversification, not compatibility with technical standards and requirements, poor packaging we would recommend to use new ways of marketing that have never used to raise competitiveness and eliminate challenges and to ensure sustainable economic growth.

Countries can use innovative marketing strategies to raise the existing capacities and also to develop the new capacities which will allow them to become an innovation-driven country.

The further research would concentrate on identifying and deep analysis of the competitiveness challenges of separate sectors in order to develop more comprehensive innovation marketing and competitiveness strategy for each sector. It finds that Armenia as also Ukraine needs to diversify its export both by country and by product. Armenia can achieve product diversification by using innovation marketing, in particular developing new products, changing the design of existing products. Encouraging cooperation and collaboration among different actors of the market, as well as international partnerships, should assist in enhancing potential and actual interests. In addition, these actions should facilitate the more efficient use of resources and capabilities to achieve the destination's economic objectives.

The results showed that the ETI-index for Ukraine is lower than for Armenia, the trend towards the 
growth of ETI-index for Armenia was also revealed, while "market access" tends to decrease. This confirms the advisability of applying innovative marketing technologies to increase access to the domestic market, assistance for movement of goods, removing barriers to economic development and international integration.

Ali Asghar Negahdary, (2013) Evaluation of the relationship between competitive advantage and export performance (case study: Iranian firms exporting biotech products, 3(1), pp. 364-367

Annual report (2012), Eu Advisory group, 2014, p. 14

Armenia's Top 10 Exports,(2011) [Retrieved 2018-01-12] Available at : http://www.worldstopexports.com/armenias-top-10exports/

Armenia economic report (2012), Yerevan, 5

Dejanllić1, Slavica Ostojić, Nemanja Damnjanović (2014).The importance of marketing innovation in new economy, p. 36

Innovation marketing definition,[Electronic resource]-mode of access: https://www.cleverism.com/lexicon/innovation-marketingdefinition/

Innovation marketing strategies,[Electronic resource]-mode of access: https://www.linkdex.com/en-gb/inked/innovativemarketing-strategies-examples/

Global enabling trade report (2004) [Retrieved 2017-12-05] Available at : http://reports.weforum.org/global-enabling-tradereport-2014/\#section=countryeconomy-profiles-armenia

Marketing Dell's Laptops, [Retrieved 2017-06-10] Available at : http://www.soc.duke.edu/ s142tm04/laptop4b.html

Meera Singh, (2012) Marketing Mix of 4P'S for Competitive Advantage, vol. 3, Issue 6, 40-43

MinFin [Retrieved 2017-09-10] Available at : https://index.minfin.com.ua/ua/economy/gdp/eximp/ (In Ukr)

National competitiveness report (2008), Armenia, Yerevan, p. 90

Porter, M. E. (1990) The Competitive Advantage of Nations. New York: Free Press, pp. 76-77

"RA Strategic Development Policy 2014-2025", Yerevan, pp. 57-58

Sineviciene, L., Shkarupa, O., Sysoyeva, L. (2018). Socio-economic and Political Channels for Promoting Innovation as a Basis for Increasing the Economic Security of the State: Comparison of Ukraine and the Countries of the European Union. SocioEconomic Challenges, 2(2), 81-93. DOI: 10.21272/sec.2(2).81-93.2018

Scott, B. R., Lodge, G. C., (1985) US Competitiveness in the World Economy, Harvard, Business School Press, Boston, MA, United States, 5

Socio- Economic Situation of Republic of Armenia (2015-2017) National Statistical Service [Retrieved 2018-03-11] Available at : http://www.armstat.am/en/

Socio-economic reports, 2008-2016, NSS, Armenia, Yerevan

Trott, P. (2004) Innovation Management and New Product Development, Pearson, pp. 415-435

The global competitiveness report: 2017-2018. Geneve: World Economic Forum [Retrieved 2018-03-12] Available at: https://www.weforum.org/reports/the-global-competitiveness-report-2017-2018

The global competitiveness report (2006). Geneve: World Economic Forum, 3

The Ukrainian Stork Breeders Association [Retrieved 2017-05-12] Available at https://usba.com.ua/en/export-goods-andservices-ukraine-has-increased-185

The Oslo manual: guidelines for collecting and interpreting innovation, third edition, OECD/European communities (2005), pp 50-51

The Global Enabling Trade Report [Retrieved 2018-03-11] Available at: http://reports.weforum.org/global-enabling-tradereport-2016/enabling-trade-rankings/

Zayilik, M.F. (2011) Features of Innovation Marketing in the Country. Bulletin of the University of Dnipropetrovs'k. Vol. 5 (2). p. 185 - 190. (In Ukr)

Ш. Ісаакян, аспірант, Єреванський державний університет (Єреван, Вірменія);

О. В. Шкарупа, к.е.н., Сумський державний університет (Суми, Україна).

Інноваційний маркетинг як інструмент підвищення конкурентоспроможності: досвід Вірменії та України

Зростання конкурентоспроможності країни напряму залежить від інноваційності бізнес-середовища, яскравим індикатором чого можна вважати здатність підприємців використовувати інноваційні технології просування продукції та послуг, передусім - на зовнішні ринки. Тому в статті висувається гіпотеза про існування позитивного впливу інноваційного маркетингу на конкурентоспроможність країни, тобто застосування інноваційних технологій маркетингових досліджень світового ринку, виявлення нових потенційних ринків для експорту, диверсифікація лінійки товарів та послуг на закордонних ринках, просування на глобальні ринки інноваційних розробок національних виробників та інші форми прояву інноваційного маркетингу - все це створює додаткові можливості для більш ефективного використання наявного в країні ресурсного потенціалу конкурентоспроможності. Економічні перетворення як у Вірменії, 
так і в Україні у періоди посткризової стабілізації підтвердили дієвість інноваційних маркетингових технологій, які застосовувалися при проведенні політичних, фінансових та інфраструктурних реформ. У статті проаналізовано поточний рівень конкурентоспроможності Вірменії, виявлено, що низький рівень здатності до інновацій є однією з основних проблем бізнес-середовища Вірменії, тому рівень впровадження інновацій в сфрері маркетингу також є низьким. Визначено шляхи, через які застосування інструментів інноваційного маркетингу може сприяти як зростанню конкурентоспроможності країни в цілому, так і вирішенню окремих проблем: диверсифікації цінових стратегій на зовнішніх ринках, формування та просування бренду країни, підвищення потенціалу конкурентоспроможності країни через соціальні медіа, просування продукції національних компаній на світових ринках, заохочення співробітництва та кооперації між міжнародними партнерствами, пошуку нових сфер та технологій експорту, зміни дизайну існуючих продуктів з високим потенціалом конкурентоспроможності на зовнішньому ринку, розробки нових продуктів тощо. У статті за допомогою статистичних методів аналізу доведено, що Вірменії необхідно диверсифрікувати свій експорт як по країнам, так і по продуктам. Досліджено індикатор Enabling Trade Index (ETI- index) як характеристику зовнішньоторговельного середовища країни. Для побудови його прогностичних даних використано метод Хольта, що дозволило побудувати експоненціально-згладжені ряди даних, визначити значення трендів та сформувати прогнози за допомогою пакета MS Excel. Cтатистичною базою для иього дослідження стали ретроспективні дані Всесвітнього економічного форуму щодо торговельного обороту за 2012-2016 роки. Розрахунки засвідчили, що ЕTI- index для України є нижчим, ніж для Вірменії, також було виявлено тендениію до зростання ETI- index для Вірменії, тоді як "доступ до ринку" має тенденцію до зменшення. Це підтверджує доцільність застосування технологій інноваційного маркетингу для зростання доступу до внутрішнього ринку, сприяння вільному руху товарів, усунення перешкод для економічного розвитку та міжнародної інтеграції.

Ключові слова: інновації, маркетинг, конкурентоспроможність країни, інноваційний розвиток, економічне зростання, ціна, дизайн, Вірменія, Україна. 